\title{
Bogoriella caseilytica gen. nov., sp. nov., a New Alkaliphilic Actinomycete from a Soda Lake in Africa

\author{
INGRID GROTH, ${ }^{1 *}$ P. SCHUMANN,${ }^{2}$ F. A. RAINEY, ${ }^{3}$ KARIN MARTIN,${ }^{1}$ BARBARA SCHUETZE, ${ }^{1}$ \\ AND K. AUGSTEN ${ }^{4}$
}

\author{
Hans-Knöll-Institut für Naturstoff-Forschung e.V., ${ }^{1}$ DSMZ-Deutsche Sammlung von Mikroorganismen und Zellkulturen \\ GmbH, Aussenstelle Jena, ${ }^{2}$ and Institut für Molekulare Biotechnologie e.V., ${ }^{4}$ \\ D-07745 Jena, and DSMZ-Deutsche Sammlung von Mikroorganismen und \\ Zellkulturen GmbH, D-38124 Braunschweig, ${ }^{3}$ Germany
}

\begin{abstract}
A new gram-positive, alkaliphilic, nonsporulating, rod-shaped bacterium is described. The organism was isolated from soda soil (Lake Bogoria, Kenya) and has the following characteristics. It is nonmotile, not acid fast, halotolerant, and microaerophilic, and optimal growth occurs at $\mathrm{pH}$ values between 9 and 10. The peptidoglycan type is of type $\mathbf{A 4 \alpha}$, with lysine as the characteristic diamino acid and glutamic acid as a component of the interpeptide bridge. The major menaquinone is $\mathrm{MK-8}\left(\mathrm{H}_{4}\right)$. The polar lipids are phosphatidylglycerol, diphosphatidylglycerol, phosphatidylinositol, and an unknown phospholipid. 12-Methyltetradecanoic acid is the predominant fatty acid. The G+C content of the DNA is $70 \mathrm{~mol} \%$. The results of $16 \mathrm{~S}$ ribosomal DNA sequence comparisons revealed that strain HKI $00088^{\mathrm{T}}$ represents a new lineage in the order Actinomycetales. Therefore, we concluded that strain $\mathrm{HKI} \mathbf{0 0 8 8}^{\mathrm{T}}$ should be assigned to a new genus and species, for which we propose the name Bogoriella caseilytica gen. nov., sp. nov. The type strain and only strain of this genus and species is HKI 0088 (= DSM 11294).
\end{abstract}

The actinomycetes are a group of morphologically and phylogenetically diverse gram-positive bacteria with high DNA guanine-plus-cytosine $(\mathrm{G}+\mathrm{C})$ contents $(>55 \mathrm{~mol} \%)$. They are widespread in nature and are able to occupy extreme habitats, such as antarctic soil (39), desert regions $(6,49)$, hot springs (2), and highly saline areas (31). Because of the biotechnologically important secondary metabolites of these organisms and their role in decomposition of hazardous chemical compounds in nature, many isolation programs have focused on actinomycetes. Since 199032 new genera of actinomycetes have been described; 24 of these new genera are monotypic. Because of the use of improved chemotaxonomic and molecular techniques, 10 of these genera were established by describing new combinations for members of previously described genera (32, 41,42 ). In addition, novel taxa have been isolated from different environmental and clinical samples, and the taxonomic positions of these taxa have been clarified by polyphasic approaches $(16,21,30,47,48)$.

In this paper we describe the morphological, physiological, chemotaxonomic, and phylogenetic characteristics of an isolate obtained from a soda soil sample collected near Lake Bogoria, Kenya. On the basis of our results and the unique taxonomic properties of the organism, we concluded that strain HKI $0088^{\mathrm{T}}$ is a member of a new genus and a new species, for which we propose the name Bogoriella caseilytica. Strain HKI 0088 is the type strain and only strain of $B$. caseilytica. This strain has been deposited in the German Collection of Microorganisms and Cell Cultures as strain DSM $11294^{\mathrm{T}}$.

\section{MATERIALS AND METHODS}

Bacterial strain and cultural conditions. Strain $\mathrm{HKI} 0088^{\mathrm{T}}$ was isolated from a sample of soda soil ( $\mathrm{pH} \mathrm{10)}$ collected by W. D. Grant in 1988 near Lake Bogoria in the Kenyan-Tanzanian Rift Valley. The sample was stored at $4^{\circ} \mathrm{C}$ and was kindly provided for investigation in 1994. Isolation of the organism involved

* Corresponding author. Mailing address: Hans-Knöll-Institut für Naturstoff-Forschung, Beutenbergstrasse 11, D-07745 Jena, Germany. Phone: 049-3641-656666. Fax: 049-3641-656600. E-mail: igroth@leutra imb-jena.de. dilution plating on medium A (8) containing (per liter) $10.0 \mathrm{~g}$ of glucose, $5.0 \mathrm{~g}$ of peptone (Difco Laboratories, Detroit, Mich.), $5.0 \mathrm{~g}$ of yeast extract (Difco), $1.0 \mathrm{~g}$ of $\mathrm{KH}_{2} \mathrm{PO}_{4}, 0.2 \mathrm{~g}$ of $\mathrm{MgSO}_{4} \cdot 7 \mathrm{H}_{2} \mathrm{O}, 40.0 \mathrm{~g}$ of NaCl, $10.0 \mathrm{~g}$ of $\mathrm{Na}_{2} \mathrm{CO}_{3}$, and $20.0 \mathrm{~g}$ of agar ( $\mathrm{pH}$ 9.6). The $\mathrm{NaCl}$ and $\mathrm{Na}_{2} \mathrm{CO}_{3}$ were autoclaved separately and were added to the organic compounds at $60^{\circ} \mathrm{C}$ before the agar medium was poured. General laboratory cultivation was performed on solid medium A or in liquid medium A. For comparison, strain HKI $0088^{\mathrm{T}}$ was also cultivated on rich $(\mathrm{R})$ medium (46) and on Bacto Nutrient Agar (Difco).

Morphological and physiological characteristics. Cell morphology was examined by phase-contrast microscopy with a model $\mathrm{BH}-2$ microscope (Olympus, Tokyo, Japan). Motility was studied by the hanging drop method. Cell dimensions were measured with an ocular $(\times 10)$ and an objective $(\times 100 / 1.25)$. Gram staining was performed by using Hucker's modification and reagents produced by bioMerieux (Marcy l'Etoile, France). The decoloriser for Gram staining was replaced by $96 \%$ (wt/vol) ethanol. Acid fastness was determined with ZiehlNeelsen stain (23). Colony morphology was studied by using a stereo microscope (Olympus model SZ 11). For scanning electron microscopy a 48-h-old strain HKI $0088^{\mathrm{T}}$ culture from medium A was suspended in a phosphate-buffered salt solution. The cells were fixed with $0.5 \%$ glutaraldehyde $(\mathrm{pH} 7.4)$, washed several times, and dehydrated in a series of ethanol concentrations. After the cells were sputter coated with gold-palladium, they were observed with a scanning electron microscope (model JSM $6300 \mathrm{~F}$; JEOL, Tokyo, Japan) at $3 \mathrm{kV}$ by using a working distance of $7 \mathrm{~mm}$.

The $\mathrm{pH}$ range for growth was determined in medium A adjusted to $\mathrm{pH}$ values between 7.2 and 10.7 with $5 \mathrm{M} \mathrm{HCl}$ or $5 \mathrm{M} \mathrm{NaOH}$ by measuring the optical density at $600 \mathrm{~nm}$ and comparing it with the optical density of uninoculated medium. Tolerance to $\mathrm{NaCl}$ was investigated by using $\mathrm{NaCl}$ concentrations between 2 and $18 \%$ (wt/vol) in medium $A$ and $R$ medium. The effects of different temperatures on growth were determined with medium $\mathrm{A}$ and Bacto Nutrient Agar incubated at $28,37,45$, and $50^{\circ} \mathrm{C}$. Oxygen requirements were studied with Generbag microaer and Generbag anaer incubation systems (bioMerieux). Acid production from carbohydrates was examined by using a modification of the oxidation-fermentation (OF) medium of Hugh and Leifson (17). The basal medium contained (per liter) $2.0 \mathrm{~g}$ of Bacto Peptone (Difco), $1.0 \mathrm{~g}$ of Bacto Meat Extract (Difco), $3.0 \mathrm{~g}$ of Bacto Agar (Difco), and $15.0 \mathrm{ml}$ of a bromothymol blue solution $(0.2 \%, \mathrm{wt} / \mathrm{vol})(\mathrm{pH} 7.2)$. In addition, the ability of the organism to utilize a broad range of carbon sources was tested by using the panel of 95 carboncontaining compounds on BIOLOG GP microplates (BIOLOG, Inc., Hayward, Calif.) and the procedure described by Miller et al. (26). The inocula for the microplates were grown on the recommended Biolog Universal Growth Medium (BIOLOG) and on Bacto Nutrient Agar. The enzyme activities in a 48-h-old culture grown on solid medium A were examined by using API ZYM galleries (bioMerieux). Utilization of organic acids was studied by using the medium described by Cowan and Steel (5) and adding the sodium salt of each organic acid at a final concentration of $0.2 \%$ (wt/ $/ \mathrm{vol}$ ) (in the case of tartrate the potassium salt was added). Nitrate reduction, urease activity, production of indole and hydrogen sulfide, hydrolysis of Tween 80 , esculin, and gelatin, and the methyl red and Voges-Proskauer reactions were examined as described by Lanyi (23). To 
examine nitrate reduction, the reagents NIT 1 and NIT 2 (bioMerieux) were used. Urease activity was tested on solidified Bacto Urea Agar Base (Difco). Indole production and the methyl red and Voges-Proskauer reactions were examined by using Kovács reagent and reagents VP 1 and VP 2 (bioMerieux), respectively. Hydrogen sulfide production was determined by using commercial test strips (Difco). Hydrolysis of gelatin was tested in medium A and Bacto Nutrient Broth (Difco) by using UV-sterilized unprocessed film strips. Decomposition of adenine, hypoxanthine, xanthine, and tyrosine was studied by using the method recommended by Gordon et al. (13). Hydrolysis of casein and potato starch was studied as described by Gledhill and Casida (12) by using Bacto Nutrient Agar (Difco) instead of brain heart infusion agar. Hydrolysis of hippurate was tested on hippurate agar (5). Cytochrome $c$ oxidase activity was studied by monitoring the oxidation of $N, N, N^{\prime}, N^{\prime}$-tetramethylphenylenediamine dihydrochloride on DrySlide oxidase (Difco). Catalase production was determined as described by Gledhill and Casida (12). Susceptibility to antibiotics was studied by placing antibiotic discs (Oxoid) on Bacto Nutrient Agar plates seeded with suspensions of strain HKI $0088^{\mathrm{T}}$.

Cell wall analysis. Purified cell wall preparations were obtained by the method of Schleifer and Kandler (37). The amino acids and peptides in cell wall hydrolysates were analyzed by two-dimensional ascending thin-layer chromatography on cellulose plates by using previously described systems (37). The amino-terminal amino acid of the interpeptide bridge was determined by dinitrophenylation as described by Schleifer (36). Whole-cell sugars were determined as alditol acetates by gas chromatography and gas chromatography-mass spectrometry as described previously (16). The molar ratios of amino acids were determined by gas chromatography and gas chromatography-mass spectrometry of $N$-heptafluorobutyryl amino acid isobutyl esters (24). The enantiomers of cell wall amino acids were analyzed by gas chromatography of $N$-pentafluoropropionyl amino acid isopropyl esters (11) on an L-Chirasil-Val column $(25 \mathrm{~m}$ by $0.25 \mathrm{~mm}$ [inside diameter]; Macherey-Nagel, Düren, Germany) by using $\mathrm{He}$ as the carrier gas at a linear velocity of $200 \mathrm{~mm} / \mathrm{s}$, and the temperature was programmed to increase from 80 to $190^{\circ} \mathrm{C}$ at a rate of $2^{\circ} \mathrm{C} / \mathrm{min}$. The instruments used for gas chromatography and gas chromatography-mass spectrometry have been described previously (16). The glycolate content of bacterial cell walls was determined by the colorimetric method of Uchida and Aida (45)

Lipid analysis. Cellular fatty acid methyl esters obtained by the method described by Stead et al. (44) were separated by gas chromatography (16) and were identified as described previously (39). Menaquinones were extracted as described by Collins et al. (4) and were analyzed by high-performance liquid chromatography (16). Polar lipids extracted by the method of Minnikin et al. (28) were identified by two-dimensional thin-layer chromatography and by spraying the preparations with specific reagents (3). The absence of mycolic acids was demonstrated by thin-layer chromatography (27).

DNA base composition. DNA was isolated and its $\mathrm{G}+\mathrm{C}$ content was determined by high-performance liquid chromatography of deoxyribonucleosides as described previously (16)

16S rDNA sequence determination and phylogenetic analysis. Genomic DNA extraction, PCR-mediated amplification of the 16S ribosomal DNA (rDNA), and sequencing of the PCR products were performed as described previously (33). The sequence reaction mixtures were electrophoresed by using a model 373A automatic DNA sequencer (Applied Biosystems, Foster City, Calif.). The 16S rDNA sequences were manually aligned with the $16 \mathrm{~S}$ rDNA sequences of members of the order Actinomycetales by using the ae2 editor (25). Evolutionary distances were calculated by the method of Jukes and Cantor (19). Phylogenetic dendrograms were reconstructed by using treeing algorithms contained in the PHYLIP package (10)

Nucleotide sequence accession number. The $16 \mathrm{~S}$ rDNA sequence determined in this study for strain HKI $0088^{\mathrm{T}}$ has been deposited in the EMBL database under accession no. Y09911.

\section{RESULTS}

Morphological and cultural characteristics. Strain HKI $0088^{\mathrm{T}}$ grew as round, slimy, slightly convex, glistening colonies that were 1 to $3 \mathrm{~mm}$ in diameter and were mainly pale yellow to intense yellow (Fig. 1). The cells were gram-positive, nonacid-fast, nonmotile, thin irregular rods or coccoid $(0.5$ to 0.8 by 1.0 to $2.5 \mu \mathrm{m}$ ) that occurred singly, in pairs, or in small clusters (Fig. 2). Sometimes filaments up to $10 \mu \mathrm{m}$ long appeared in the populations. Endospores were never observed. Scanning electron micrographs (Fig. 3) revealed the presence of spiky structures distributed over the whole surface of each cell. Such spikes have not been found previously in coryneform bacteria. They may be comparable to the nonprosthecate appendages of the gram-negative spinate bacteria (9). The socalled spinae are distinct from flagella and pili. In the case of isolate HKI $0088^{\mathrm{T}}$ further investigation will be necessary to clarify the chemical composition of these structures, their pos-

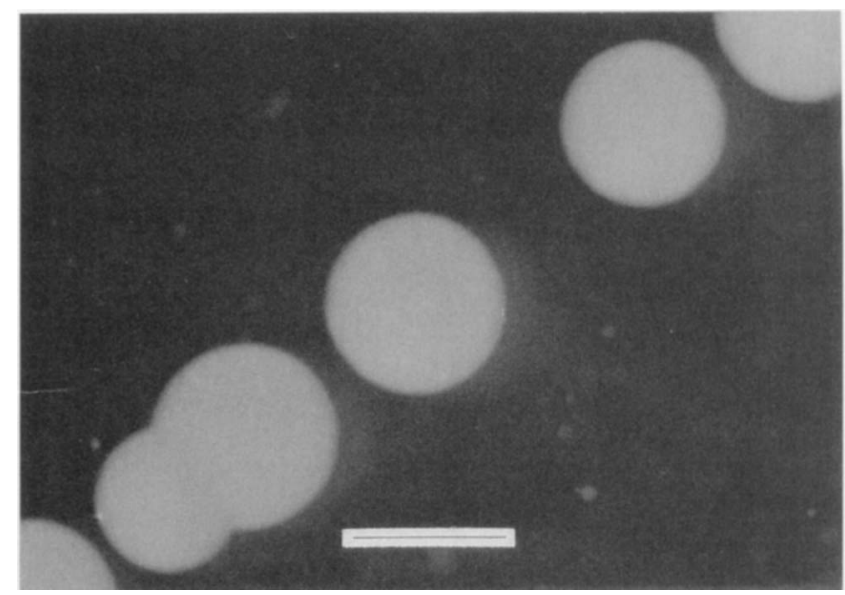

FIG. 1. Single colonies of strain HKI $0088^{\mathrm{T}}$ grown on solid medium A at $28^{\circ} \mathrm{C}$ for 6 days. Bar $=1 \mathrm{~mm}$

sible function as a reflection of adaptation to the special alkaline ecological niche, and their taxonomic significance. Strain HKI $0088^{\mathrm{T}}$ was isolated on alkaline medium $\mathrm{A}(\mathrm{pH} 9.6)$ but was able to grow at pH 7.2 on Bacto Nutrient Agar and R medium at 28 and $37^{\circ} \mathrm{C}$. Growth at neutral $\mathrm{pH}$ on agar media was delayed and reduced, especially at $37^{\circ} \mathrm{C}$ and after serial transfers. At $45^{\circ} \mathrm{C}$ only traces of growth were observed on media at neutral and alkaline $\mathrm{pH}$ values. At $50^{\circ} \mathrm{C}$ no growth occurred. The optimum initial $\mathrm{pH}$ for growth in liquid medium A ranged from 8.8 to 10.1 , indicating that strain $\mathrm{HKI} 0088^{\mathrm{T}}$ is an alkaliphilic organism $(14,15)$ which is able to grow well under aerobic conditions and in the presence of reduced $\mathrm{O}_{2}$ concentrations. In an anaerobic atmosphere, however, traces of growth were observed. $\mathrm{NaCl}$ in alkaline medium $\mathrm{A}$ did not influence growth at $\mathrm{NaCl}$ concentrations up to $8 \%$ (wt/vol). At an $\mathrm{NaCl}$ concentration of $10 \%$ (wt/vol) growth was markedly reduced, and poor growth occurred in the presence of $18 \%$ (wt/vol) $\mathrm{NaCl}$. In $\mathrm{R}$ medium growth occurred in the presence of $\mathrm{NaCl}$ concentrations up to $6 \%$ (wt/vol). Only traces of poor growth were observed in the presence of $\mathrm{NaCl}$ concentrations between 8 and $14 \%$ (wt/vol).

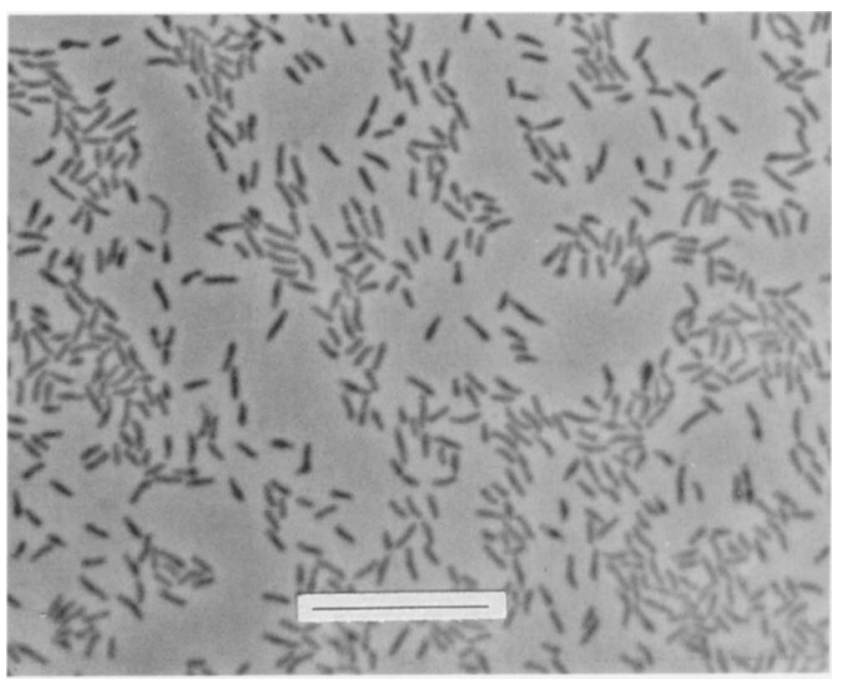

FIG. 2. Micrograph of strain HKI $0088^{\mathrm{T}}$ cells grown in liquid medium A at $28^{\circ} \mathrm{C}$ for $24 \mathrm{~h}$. Bar $=10 \mu \mathrm{m}$. 


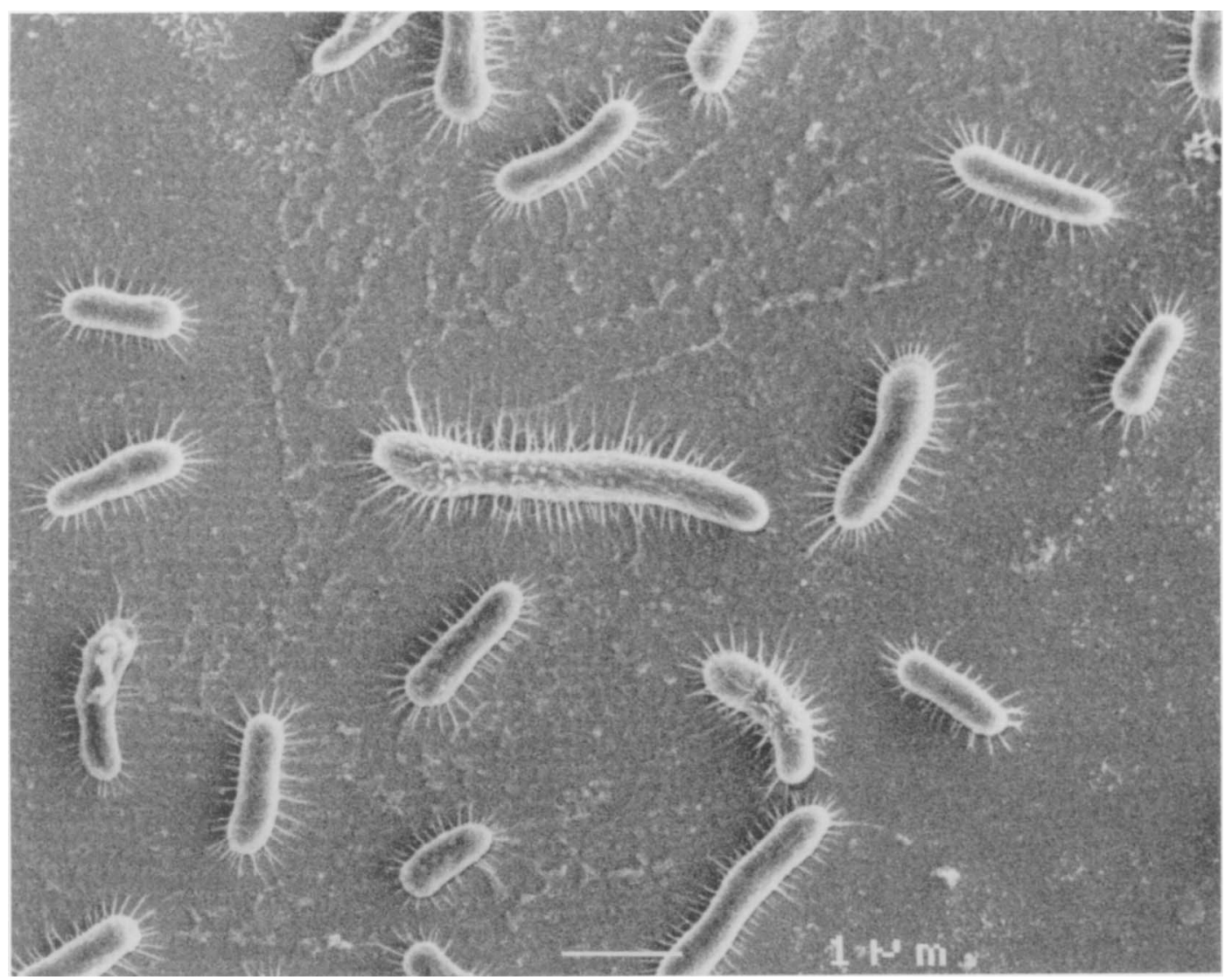

FIG. 3. Scanning electron micrograph of cells from a 48 -h-old culture of strain HKI $0088^{\mathrm{T}}$ grown at $28^{\circ} \mathrm{C}$ on solid medium A. Bar $=1 \mu \mathrm{m}$.

Physiological characteristics. The physiological properties of strain HKI $0088^{\mathrm{T}}$ are shown in Tables 1 and 2 . The ability of strain HKI $0088^{\mathrm{T}}$ to utilize a broad range of carbon sources was demonstrated by the classical method of Hugh and Leifson (17) and by the microplate technique (Biolog system). Except for inulin and L-rhamnose, there was a good correlation between the results obtained with the two different methods for the carbon sources tested. The activities of some enzymes of carbohydrate metabolism determined with the API ZYM method (Table 1) confirmed these results. Cultivation of the inoculum for the GP microplates on Bacto Nutrient Agar gave similar good results compared with the results obtained with Biolog Universal Growth Medium. The alkali salts of the organic acids acetate, aconitate, benzoate, citrate, formate, malate, succinate, and tartrate were not used for growth. Nitrogenous compounds like ammonia, nitrate, hippurate, and urea were not utilized. Strain HKI $0088^{\mathbf{T}}$ prefered complex nitrogenous compounds, such as peptone and casein, for growth. Gelatin was hydrolyzed in alkaline medium A when peptone was limited in the stationary growth phase. Due to the reduced growth at neutral $\mathrm{pH}$, no peptone limitation occurred, and gelatin was not attacked. Esculin was hydrolyzed, but adenine, hypoxanthine, tyrosine, Tween 80 , and xanthine were not decomposed. Strain HKI $0088^{\mathrm{T}}$ was susceptible to all of the antibiotics tested except nitrofuran and sulfonamid.

Chemotaxonomic characteristics. The peptidoglycan of strain HKI $0088^{\mathrm{T}}$ was characterized by the presence of lysine (Lys), alanine (Ala), and glutamic acid (Glu) at a molar ratio of 1.0:4.3:2.1. Glu was found to be the amino-terminal amino acid of the interpeptide bridge. The analysis of the enanti- omers of the cell wall amino acids resulted in detection of L-Lys, detection of D-Ala and L-Ala (molar ratio, 1:3.5), and detection of D-Glu and L-Glu (molar ratio, 1:1.8). From these results and from the two-dimensional thin-layer chromatographic peptide patterns of partial hydrolysates of cell walls, we concluded that strain HKI $0088^{\mathrm{T}}$ represents a new variation of peptidoglycan type $\mathrm{A} 4 \alpha(7,37)$ with an $\mathrm{L}-\mathrm{Lys} \leftarrow \mathrm{L}-\mathrm{Ala} \leftarrow \mathrm{L}-$ Ala $\leftarrow$ L-Glu interpeptide bridge. The acyl type is acetyl. Galactose was the only whole-cell sugar. The polar lipids were phosphatidylglycerol, diphosphatidylglycerol, phosphatidylinositol, and an unknown phospholipid. The fatty acid profile was characterized by the predominance of 12-methyltetradecanoic acid (ai- $\mathrm{C}_{15: 0}$ ) and by the presence of iso- and anteiso-branched acids as minor components (Table 3 ). The menaquinones were MK-8 $\left(\mathrm{H}_{4}\right)$ and MK-9 $\left(\mathrm{H}_{4}\right)$ (peak area ratio, 87:11). No mycolic acids were present. The $\mathrm{G}+\mathrm{C}$ content of the DNA of strain HKI $0088^{\mathrm{T}}$ was $70 \mathrm{~mol} \%$.

16S rDNA sequence analysis. An almost complete $16 \mathrm{~S}$ rDNA sequence comprising 1,476 nucleotides $(>95 \%$ of the Escherichia coli sequence [1]) was determined for strain HKI $0088^{\mathrm{T}}$. The phylogenetic dendrogram in Fig. 4 was reconstructed from evolutionary distances by the neighbor-joining method (35). A total of 1,322 nucleotides present in all of the strains between positions 41 and 1458 (E. coli numbering [1]) were used for this analysis. The phylogenetic dendrogram (Fig. 4) shows that strain HKI $0088^{\mathrm{T}}$ falls within the radiation of the order Actinomycetales. This strain represents a distinct lineage that exhibits 90.1 to $93.4 \% 16 \mathrm{~S}$ rDNA sequence similarity to the other members of the cluster included in the analysis (data not shown). 
TABLE 1. Physiological properties of strain HKI $0088^{\mathrm{T}}$

\begin{tabular}{|c|c|}
\hline Characteristic & $\begin{array}{l}\text { Reaction } \\
\text { strain HK } \\
\quad 0088^{\mathrm{T}}\end{array}$ \\
\hline \multicolumn{2}{|l|}{ Decomposition of: } \\
\hline \multicolumn{2}{|c|}{ Casein } \\
\hline \multicolumn{2}{|c|}{ Esculin } \\
\hline \multicolumn{2}{|c|}{ Gelatin } \\
\hline \multicolumn{2}{|c|}{ 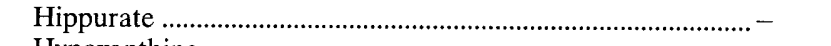 } \\
\hline \multicolumn{2}{|c|}{ Hypoxanthine .................................................................. - } \\
\hline \multicolumn{2}{|c|}{ 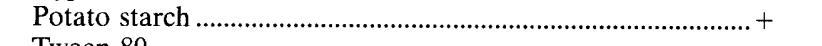 } \\
\hline \multicolumn{2}{|c|}{ 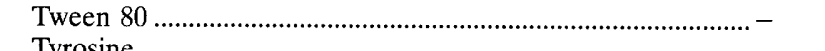 } \\
\hline \multicolumn{2}{|c|}{ Tyrosine …........................................................................ } \\
\hline \multirow{2}{*}{\multicolumn{2}{|c|}{ Urea }} \\
\hline & \\
\hline \multicolumn{2}{|l|}{ Acid produced from: } \\
\hline \multirow{2}{*}{\multicolumn{2}{|c|}{ L-Arabinose . }} \\
\hline \multirow{2}{*}{\multicolumn{2}{|c|}{ D-Cellobiose }} \\
\hline & \\
\hline \multicolumn{2}{|c|}{ 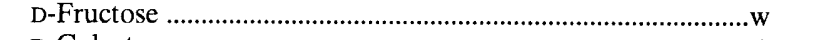 } \\
\hline D-Galactose ...................... & \\
\hline D-Glucitol........................... & \\
\hline 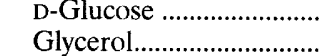 & $\begin{array}{c}+ \\
+ \\
+\end{array}$ \\
\hline 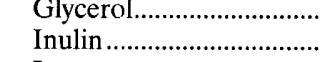 & $\ldots+$ \\
\hline 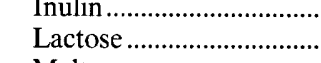 & n..... \\
\hline 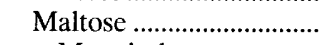 & $\ldots \ldots \ldots . . . W$ \\
\hline 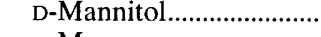 & \\
\hline 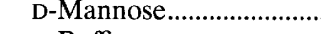 & \\
\hline D-Raffinose ........................... & .........w \\
\hline L-Rhamnose....................... & ......... \\
\hline D-Ribose ............................ & ......... \\
\hline Salicin ................................ & .......... \\
\hline 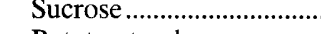 & \\
\hline 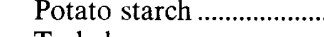 & .......... \\
\hline 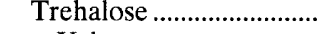 & .......... \\
\hline D-Xylose .................................. & \\
\hline Utilization of: & \\
\hline Acetate ................................. & .......- \\
\hline Aconitate .......................... & ......- \\
\hline Benzoate ............................. & $\ldots-$ \\
\hline Citrate ............................. & \\
\hline Formate ............................. & \\
\hline Malate ................................. & \\
\hline Succinate........................... & \\
\hline DL-Tartrate & \\
\hline Enzyme activities (API ZY & \\
\hline Phosphatase (alkaline).. & \\
\hline 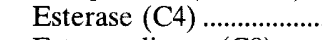 & ......... \\
\hline Esterase-lipase (C8) ....... & ......... \\
\hline 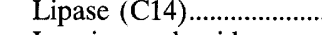 & \\
\hline Leucine arylamidase....... & ......... \\
\hline Valine arylamidase ........ & ........- \\
\hline Cystine arylamidase....... & .........- \\
\hline Trypsin & $\ldots \ldots .$. \\
\hline 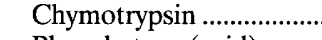 & \\
\hline Phosphatase (acid) ........ & ......... \\
\hline Naphthol-AS-BI-phosph & ........- \\
\hline$\alpha$-Galactosidase ........... & \\
\hline$\beta$-Galactosidase .................. & ......... + \\
\hline$\beta$-Glucuronidase .............. & $\ldots \ldots .$. \\
\hline$\alpha$-Glucosidase ....................... & ........ \\
\hline 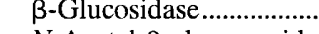 & ........ \\
\hline$N$-Acetyl- $\beta$-glucosamida & ........ \\
\hline$\alpha$-Mannosidase .............. & ........ \\
\hline$\alpha$-Fucosidase ................. & \\
\hline Nitrate reduction ...................... & ........- \\
\hline Production of $\mathrm{H}_{2} \mathrm{~S} \ldots \ldots \ldots \ldots$ & \\
\hline Catalase reaction .................... & ......... \\
\hline Voges-Proskauer test ....... & \\
\hline
\end{tabular}

TABLE 1-Continued

Characteristic
Methyl red test.
Oxidase test
Indole test
Growth in the presence of:
$2 \% \mathrm{NaCl}$
$4 \% \mathrm{NaCl}$
$6 \% \mathrm{NaCl}$
stain $^{2}$

\section{DISCUSSION}

Soda lakes in Kenya are interesting naturally occurring alkaline environments with different levels of salinity $(14,15)$. As they are assumed to harbor numerous novel taxa, their microbial diversity will be explored more $(8,14,15,18,29,50,51)$. The recent findings of Duckworth et al. (8) support our conclusion based on an investigation of six different soil or watersediment samples from this area that the gram-positive isolates were mainly members of the genus Bacillus. Despite of the long storage of the samples (6 years) at $4^{\circ} \mathrm{C}$, we isolated actinomycetes which we identified on the basis of morphological and chemotaxonomic characteristics as members of the genera Aureobacterium, Arthrobacter, Nesterenkonia, Micrococcus, Cellulomonas, Clavibacter, Rhodococcus, Nocardia, Nocardiopsis, Micromonospora, and Streptomyces. To our knowledge, isolate HKI $0088^{\mathrm{T}}$ represents the first novel genus of high-G+Ccontent gram-positive bacteria from the soda lakes. The results of our $16 \mathrm{~S}$ rDNA sequence comparisons clearly demonstrated the distinct position of strain $\mathrm{HKI} 0088^{\mathrm{T}}$ within the radiation of the actinomycetes. This was demonstrated both by the phylogenetic dendrogram and by the range of levels of $16 \mathrm{~S}$ rDNA sequence similarity to other taxa. Genus status was also supported by the results of the chemotaxonomic analyses.

The structure of the peptidoglycan of strain HKI $0088^{\mathrm{T}}$ represents a variation of type $\mathrm{A} 4 \alpha$ (37) with an L-Lys $\leftarrow$ LAla $\leftarrow$ L-Ala $\leftarrow$ L-Glu interpeptide bridge which has not been 
TABLE 2. Utilization of different substrates as sole carbon sources for respiration (formation of NADH) by strain HKI $0088^{\mathrm{T}}$ after cultivation on two different media

\begin{tabular}{|c|c|c|}
\hline \multirow{2}{*}{ Carbon source } & \multicolumn{2}{|c|}{ Utilization on: } \\
\hline & $\mathrm{BUGM}^{a}$ & $\mathbf{N A}^{a}$ \\
\hline$\alpha$-Cyclodextrin & $+^{b}$ & + \\
\hline$\beta$-Cyclodextrin & + & + \\
\hline Dextrin & + & + \\
\hline Glycogen & + & + \\
\hline Inulin & - & - \\
\hline Mannan & - & - \\
\hline Tween 40 & - & - \\
\hline Tween 80 & - & - \\
\hline $\mathrm{N}$-Acetylglucosamine & - & - \\
\hline $\mathrm{N}$-Acetylmannosamine & - & - \\
\hline Amygdalin & + & + \\
\hline L-Arabinose & + & + \\
\hline D-Arabitol & + & + \\
\hline Arbutin & + & + \\
\hline Cellobiose & + & + \\
\hline D-Fructose & + & + \\
\hline L-Fucose & + & + \\
\hline D-Galactose & + & + \\
\hline D-Galacturonic acid & $\mathrm{w}$ & - \\
\hline Gentiobiose & + & + \\
\hline D-Gluconic acid & - & - \\
\hline$\alpha$-D-Glucose & + & + \\
\hline$m$-Inositol & - & - \\
\hline$\alpha$-D-Lactose & + & + \\
\hline Lactulose & + & + \\
\hline Maltose & + & + \\
\hline Maltotriose & + & + \\
\hline D-Mannitol & + & + \\
\hline D-Mannose & + & + \\
\hline D-Melezitose & + & + \\
\hline D-Melibiose & + & + \\
\hline$\alpha$-Methyl-D-galactoside & - & - \\
\hline$\beta$-Methyl-D-galactoside & + & + \\
\hline 3-Methylglucose & + & + \\
\hline$\alpha$-Methyl-D-glucoside & - & - \\
\hline$\beta$-Methyl-D-glucoside & + & + \\
\hline$\alpha$-Methyl-D-mannoside & + & + \\
\hline Palatinose & + & + \\
\hline D-Psicose & - & - \\
\hline D-Raffinose & + & + \\
\hline L-Rhamnose & - & - \\
\hline D-Ribose & + & + \\
\hline Salicin & + & + \\
\hline Sedoheptulosan & - & - \\
\hline D-Sorbitol & + & + \\
\hline Stachyose & $\mathrm{w}$ & $\mathrm{w}$ \\
\hline Sucrose & + & + \\
\hline D-Tagatose & + & + \\
\hline D-Trehalose & + & + \\
\hline Turanose & + & + \\
\hline Xylitol & - & - \\
\hline D-Xylose & + & + \\
\hline Acetic acid & - & - \\
\hline$\alpha$-Hydroxybutyric acid & + & + \\
\hline$\beta$-Hydroxybutyric acid & - & - \\
\hline$\gamma$-Hydroxybutyric acid & - & - \\
\hline p-Hydroxyphenylacetic acid & - & - \\
\hline$\alpha$-Ketoglutaric acid & - & - \\
\hline$\alpha$-Ketovaleric acid & - & - \\
\hline Lactamide & - & - \\
\hline D-Lactic acid methyl ester & - & - \\
\hline L-Lactic acid & - & - \\
\hline D-Malic acid & - & - \\
\hline L-Malic acid & - & \\
\hline
\end{tabular}

TABLE 2-Continued

\begin{tabular}{|c|c|c|}
\hline \multirow{2}{*}{ Carbon source } & \multicolumn{2}{|c|}{ Utilization on: } \\
\hline & $\mathrm{BUGM}^{a}$ & $\mathrm{NA}^{a}$ \\
\hline Methylpyruvate & + & + \\
\hline Methylsuccinate & + & - \\
\hline Propionic acid & - & - \\
\hline Pyruvic acid & + & + \\
\hline Succinamic acid & - & - \\
\hline Succinic acid & - & - \\
\hline$N$-Acetyl-L-glutamic acid & - & - \\
\hline Alaninamide & - & - \\
\hline D-Alanine & - & - \\
\hline L-Alanine & - & - \\
\hline L-Alanyl-glycine & - & - \\
\hline L-Asparagine & - & - \\
\hline L-Glutamic acid & - & - \\
\hline Glycyl-L-glutamic acid & - & - \\
\hline L-Pyroglutamic acid & - & - \\
\hline L-Serine & - & - \\
\hline Putrescine & - & - \\
\hline 2,3-Butanediol & - & - \\
\hline Glycerol & + & + \\
\hline Adenosine & - & - \\
\hline $2^{\prime}$-Deoxyadenosine & - & - \\
\hline Inosine & - & - \\
\hline Thymidine & - & - \\
\hline Uridine & - & - \\
\hline AMP & - & - \\
\hline TMP & - & - \\
\hline UMP & - & - \\
\hline Fructose 6-phosphate & - & - \\
\hline Glucose 1-phosphate & - & - \\
\hline Glucose 6-phosphate & - & - \\
\hline DL- $\alpha$-Glycerophosphate & w & - \\
\hline
\end{tabular}

${ }^{a}$ BUGM, Biolog Universal Growth Medium; NA, Bacto Nutrient Agar (Difco)

${ }_{b}+$, positive; - , negative; $w$, weakly positive.

reported previously $(7,37,38)$. Type A11.35 (7), a similar variation of peptidoglycan type A4 $\alpha$ with an $\mathrm{L}-\mathrm{Lys} \leftarrow \mathrm{L}-\mathrm{Ala} \leftarrow \mathrm{L}-$ Glu interpeptide bridge, has been found in Arthrobacter nicotianae DSM 20123, Arthrobacter uratoxydans DSM $20647^{\mathrm{T}}$, and Brevibacterium liquefaciens DSM $20579^{\mathrm{T}}$ (considered synonymous with $A$. nicotianae) (40). These species are clearly different from our strain; their menaquinones are MK-8 and MK-9 menaquinones, they lack the phospholipid phosphatidylinositol, and their DNA G+C contents are lower (60 to $66 \mathrm{~mol} \%)$ $(20,40)$. The typical rod-coccus growth cycle of Arthrobacter species was not found in strain HKI $0088^{\mathrm{T}}$. Isolate HKI $0088^{\mathrm{T}}$

TABLE 3. Cellular fatty acid composition of strain HKI $0088^{\mathrm{T}}$

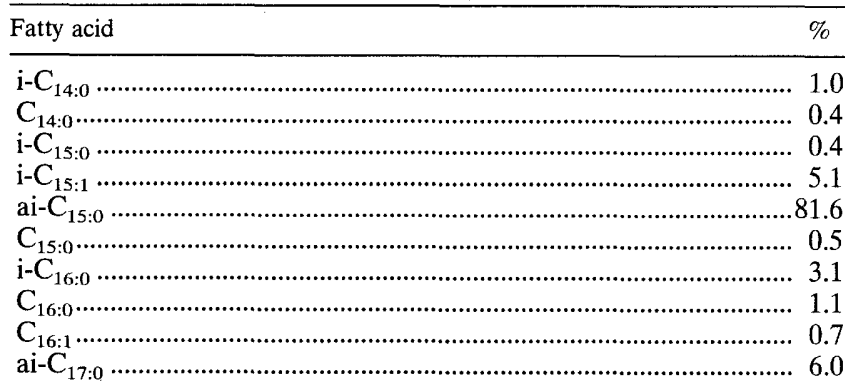

${ }^{a}$ The abbreviations for fatty acids are illustrated by the following examples $\mathrm{C}_{16: 0}$, hexadecanoic acid; $\mathrm{C}_{18: 1}$, octadecenoic acid; $\mathrm{i}-\mathrm{C}_{15: 0}, 13$-methyltetradecanoic acid; ai- $\mathrm{C}_{15: 0}, 12$-methyltetradecanoic acid. 


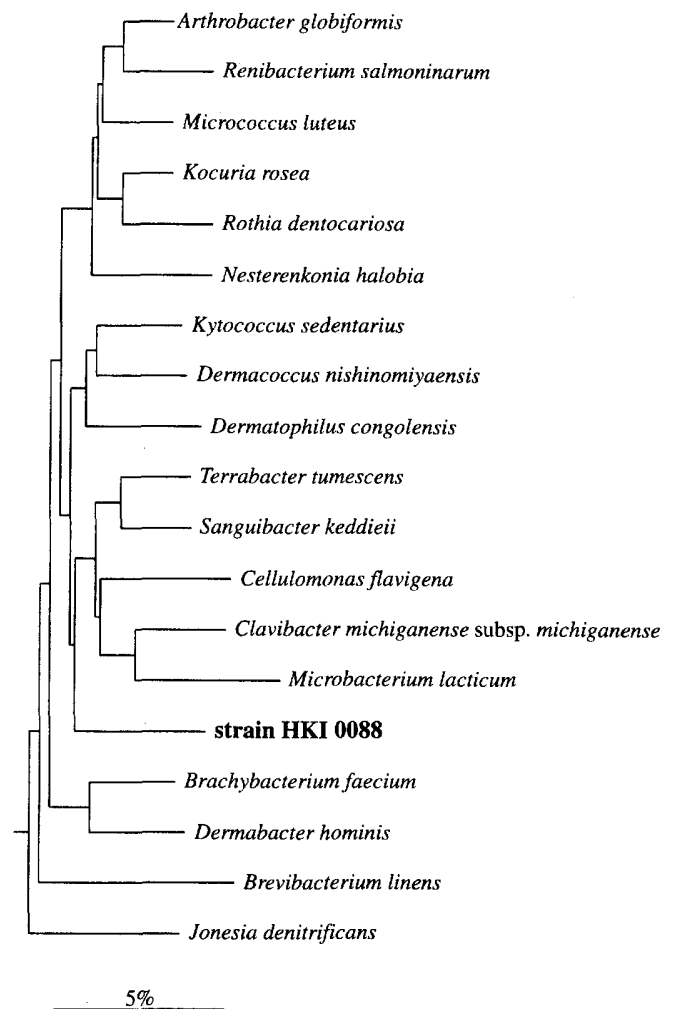

FIG. 4. 16S rDNA sequence-based phylogenetic dendrogram reconstructed from evolutionary distances by using the neighbor-joining method (35). Scale bar $=5$ inferred nucleotide substitutions per 100 nucleotides.

is also phylogenetically clearly distinct from the other $\mathrm{A} 4 \alpha$ peptidoglycan-containing species, such as $A$. nicotianae and Cellulomonas turbata, which have been shown previously to cluster with the respective type species of their genera $(22,34)$. The same is true for the differentiation of strain HKI $0088^{\mathrm{T}}$ from the MK- $8\left(\mathrm{H}_{4}\right)$-containing organisms Nocardioides albus and Nocardioides simplex, which have been shown to be members of the suborder Propionibacterineae, a distinct phylogenetic group within the Actinomycetales (43) that is separate from the suborder Micrococcineae (43), into which strain HKI $0088^{\mathrm{T}}$ falls.

On the basis of the results described above and in view of the uniqueness of some of the taxonomic properties, we propose that strain HKI $0088^{\mathrm{T}}$ represents a new genus in the order Actinomycetales.

Description of Bogoriella gen. nov. Bogoriella (Bo.go.ri.el'la. M. L. dim. fem. n. Bogoriella, named after Lake Bogoria in Kenya, the place from which isolate HKI $0088^{\mathrm{T}}$ originated). Cells are irregular and rod shaped or coccoid and occur singly, in pairs, or in small irregular clusters. The cells are gram positive, not acid fast, and nonmotile. Endospores are not formed. Aerobic or microaerophilic. Very poor growth can occur under anaerobic conditions. Catalase positive and oxidase negative. The peptidoglycan type is type A4 $\alpha$ with lysine as the characteristic diamino acid. The acyl type is acetyl. The phospholipids are phosphatidylglycerol, diphosphatidylglycerol, phosphatidylinositol, and an unknown phospholipid. Mycolic acids are absent, and the cellular fatty acids are of the isoand anteiso-branched type; 12-methyltetradecanoic acid is the major fatty acid. The major menaquinone is $\mathrm{MK}-8\left(\mathrm{H}_{4}\right)$. The $\mathrm{G}+\mathrm{C}$ content of the DNA is $70 \mathrm{~mol} \%$. The type species is Bogoriella caseilytica.
Description of Bogoriella caseilytica sp. nov. Bogoriella caseilytica (ca. sei.ly' ti.ca. L. n. caseus, cheese; Gr. v. lyein, to loosen, dissolve; M. L. fem. adj. caseilytica, loosening or dissolving casein). Cells are irregular and rod shaped or coccoid and occur singly, in pairs, or in small clusters. The cells are 0.5 to 0.8 by 1.0 to $2.5 \mu \mathrm{m}$, gram positive, not acid fast, and nonmotile, and no endospores are formed. A few cells may be filamentous and up to $10 \mu \mathrm{m}$ long. Colonies are round, smooth, slightly convex, glistening, and 1 to $3 \mathrm{~mm}$ in diameter. The colony color varies from pale yellow to intense yellow. Alkaliphilic. Optimal growth occurs at $\mathrm{pH} 9$ to 10 and at 28 to $37^{\circ} \mathrm{C}$. $\mathrm{NaCl}$ tolerant. Aerobic or microaerophilic. Acids are produced from L-arabinose, D-cellobiose, dextrin, D-fructose, D-galactose, D-glucose, D-glucitol, glycerol, inulin, lactose, maltose, D-mannitol, D-mannose, D-raffinose, L-rhamnose, D-ribose, salicin, sucrose, potato starch, trehalose, and D-xylose. Acetate, aconitate, benzoate, citrate, formate, malate, succinate, and tartrate are not utilized as carbon sources. Starch, esculin, casein, and gelatin are hydrolyzed. Urea, hippurate, adenine, hypoxanthine, xanthine, tyrosine, and Tween 80 are not decomposed or hydrolyzed. Nitrate is not reduced to nitrite. Hydrogen sulfide is produced; indole is not produced. Methyl red and Voges-Proskauer reactions are negative. Catalase positive and oxidase negative. Cells are susceptible to ampicillin, chloramphenicol, ciprofloxacin, erythromycin, gentamicin, kanamycin, lincomycin, neomycin, oxacillin, oxytetracycline, penicillin G, polymyxin B, rifampin, and streptomycin. Cells are resistant to nitrofuran and sulfonamid. The habitat is soil. The $\mathrm{G}+\mathrm{C}$ content is $70 \mathrm{~mol} \%$. The type strain is strain HKI 0088 (= DSM 11294).

\section{ACKNOWLEDGMENTS}

This work was supported by grant $0310591 \mathrm{~A}$ from the Bundesministerium für Bildung, Wissenschaft, Forschung und Technologie, Germany.

We are grateful to W. D. Grant, Department of Microbiology, University of Leicester, United Kingdom, for providing soil samples. We acknowledge Jutta Meyer for a critical review of the manuscript. We thank Christiane Weigel and Carmen Schult for excellent technical assistance.

\section{REFERENCES}

1. Brosius, J., M. L. Palmer, P. J. Kennedy, and H. F. Noller. 1978. Complete nucleotide sequence of the $16 \mathrm{~S}$ ribosomal RNA gene from Escherichia coli. Proc. Natl. Acad. Sci. USA 75:4801-4805.

2. Carreto, L., E. Moore, M. F. Nobre, R. Wait, P. W. Riley, R. J. Sharp, and M. S. Da Costa. 1996. Rubrobacter xylanophilus sp. nov.: a new thermophilic species isolated from a thermally polluted effluent. Int. J. Syst. Bacteriol. 46:460-465.

3. Collins, M. D., and D. Jones. 1980 . Lipids in the classification and identification of coryneform bacteria containing peptidoglycans based on 2,4-diaminobutyric acid. J. Appl. Bacteriol. 48:459-470.

4. Collins, M. D., T. Pirouz, M. Goodfellow, and D. E. Minnikin. 1977. Distribution of menaquinones in actinomycetes and corynebacteria. J. Gen. Microbiol. 100:221-230.

5. Cowan, S. T., and K. J. Steel. 1965. Manual for the identification of medical bacteria. Cambridge University Press, Cambridge, United Kingdom.

6. Dobrovolskaya, T. G., 1. Y. Chernov, L. V. Lysak, G. M. Zenova, T. A. Gracheva, and D. G. Zvyagintsev. 1994. Bacterial communities of the Kyzyl Kum desert: spatial distribution and taxonomic composition. Mikrobiologiya 63:188-192.

7. DSM-Deutsche Sammlung von Mikroorganismen und Zellkulturen GmbH. 1993. Catalogue of strains, 5th ed. DSM-Deutsche Sammlung von Mikroorganismen und Zellkulturen $\mathrm{GmbH}$, Braunschweig, Germany.

8. Duckworth, A. W., W. D. Grant, B. E. Jones, and R. van Steenbergen. 1996 Phylogenetic diversity of soda lake alkaliphiles. FEMS Microbiol. Ecol. 19: 181-191.

9. Easterbrook, K. B. 1989. Spinate bacteria, p. 1991-1993. In J. T. Staley, M. P. Bryant, N. Pfennig, and J. G. Holt (ed.), Bergey's manual of systematic bacteriology, vol. 3. Williams \& Wilkins, Baltimore, Md.

10. Felsenstein, J. 1993. PHYLIP (phylogenetic inference package), version 3.5.1. Department of Genetics, University of Washington, Seattle. 
11. Frank, H., A. Rettenmeier, H. Weicker, G. J. Nicholson, and E. Bayer. 1980. A new gas chromatographic method for determination of amino acid levels in human serum. Clin. Chim. Acta 105:201-211.

12. Gledhill, W. E., and L. E. Casida, Jr. 1969. Predominant catalase-negative soil bacteria. III. Agromyces, gen. n., microorganisms intermediary to Actinomyces and Nocardia. Appl. Microbiol. 18:340-349.

13. Gordon, R. E., D. A. Barnett, J. E. Handerhan, and C. H.-N. Pang. 1974. Nocardia coeliaca, Nocardia autotrophica, and the nocardin strain. Int. J. Syst. Bacteriol. 24:54-63.

14. Grant, W. D. 1992. Alkaline environments, p. 73-80. In J. Lederberg (ed.) Encyclopedia of microbiology. Academic Press, London, United Kingdom.

15. Grant, W. D., W. E. Mwatha, and B. E. Jones. 1990. Alkaliphiles: ecology, diversity and applications. FEMS Microbiol. Rev. 75:255-270.

16. Groth, I., P. Schumann, N. Weiss, K. Martin, and F. A. Rainey, 1996 Agrococcus jenensis gen. nov., sp. nov., a new genus of actinomycetes with diaminobutyric acid in the cell wall. Int. J. Syst. Bacteriol. 46:234-239.

17. Hugh, R., and E. Leifson. 1953. The taxonomic significance of fermentative versus oxidative metabolism of carbohydrates by various Gram negative bacteria. J. Bacteriol. 66:24-26.

18. Jones, B. E., W. D. Grant, N. C. Collins, and W. E. Mwatha. 1994. Alkaliphiles: diversity and identification, p. 195-229. In F. G. Priest, A. RamosCormazana, and B. J. Tindall (ed.), Bacterial diversity and systematics. Plenum Press, New York, N.Y.

19. Jukes, T. H., and C. R. Cantor. 1969. Evolution of protein molecules, p 21-132. In H. N. Munro (ed.), Mammalian protein metabolism. Academic Press, New York, N.Y.

20. Keddie, R. M., M. D. Collins, and D. Jones. 1986. Genus Arthrobacter Conn and Dimmick $1947,300^{\mathrm{AL}}$, p. $1288-1301$. In P. H. A. Sneath, N. S. Mair M. E. Sharpe, and J. G. Holt (ed.), Bergey's manual of systematic bacteriology, vol. 2. Williams \& Wilkins, Baltimore, Md.

21. Kleespies, M., R. M. Kroppenstedt, F. A. Rainey, L. E. Webb, and E. Stackebrandt. 1996. Mycobacterium hodleri sp. nov., a new member of the fastgrowing mycobacteria capable of degrading polycyclic aromatic hydrocarbons. Int. J. Syst. Bacteriol. 46:683-687.

22. Koch, C., F. A. Rainey, and E. Stackebrandt. 1994. 16S rDNA studies on members of Arthrobacter and Micrococcus: an aid for their future taxonomic restructuring. FEMS Microbiol. Lett. 123:167-172.

23. Lanyi, B. 1987. Classical and rapid identification methods for medically important bacteria. Methods Microbiol. 19:1-67.

24. MacKenzie, S. L. 1987. Gas chromatographic analysis of amino acids as the N-heptafluorobutyryl isobutyl esters. J. Assoc. Off. Anal. Chem. 70:151-160.

25. Maidak, B. L., N. Larsen, M. J. McCaughey, R. Overbeek, G. J. Olsen, K. Fogel, J. Blandy, and C. R. Woese. 1994. The Ribosomal Database Project Nucleic Acids Res. 22:3485-3487.

26. Miller, J. M., J. W. Biddle, V. K. Quenzer, and J. C. McLaughlin. 1993. Evaluation of Biolog for identification of members of the family Micrococcaceae. J. Clin. Microbiol. 31:3170-3173.

27. Minnikin, D. E., L. Alshamaony, and M. Goodfellow. 1975. Differentiation of Mycobacterium, Nocardia, and related taxa by thin-layer chromatographic analysis of whole-organism methanolysates. J. Gen. Microbiol. 88:200-204.

28. Minnikin, D. E., M. D. Collins, and M. Goodfellow. 1979. Fatty acid and polar lipid composition in the classification of Cellulomonas, Oerskovia and related taxa. J. Appl. Bacteriol. 47:87-95.

29. Mwatha, W. E., and W. D. Grant. 1993. Natronobacterium vacuolata sp. nov. a haloalkaliphilic archeon isolated from Lake Magadi, Kenya. Int. J. Syst. Bacteriol. 43:401-404.

30. Nakamura, K., A. Hiraishi, Y. Yoshimi, M. Kawaharasaki, K. Masuda, and Y. Kamagata. 1995. Microlunatus phosphovorus gen. nov., sp. nov., a new gram-positive polyphosphate-accumulating bacterium isolated from activated sludge. Int. J. Syst. Bacteriol. 45:17-22.

31. Onishi, H., and M. Kamekura. 1972. Micrococcus halobius sp. n. Int. J. Syst. Bacteriol. 22:233-236.

32. Rainey, F. A., S. Klatte, R. M. Kroppenstedt, and E. Stackebrandt. 1995 Dietzia, a new genus including Dietzia maris comb. nov., formerly Rhodococcus maris. Int. J. Syst. Bacteriol. 45:32-36.

33. Rainey, F. A., N. Ward-Rainey, R. M. Kroppenstedt, and E. Stackebrandt.
1996. The genus Nocardiopsis represents a phylogenetically coherent taxon and a distinct actinomycete lineage: proposal of Nocardiopsaceae fam. nov. Int. J. Syst. Bacteriol. 46:1088-1092.

34. Rainey, F. A., N. Weiss, and E. Stackebrandt. 1995. Phylogenetic analysis of the genera Cellulomonas, Promicromonospora, and Jonesia and proposal to exclude the genus Jonesia from the family Cellulomonadaceae. Int. J. Syst. Bacteriol. 45:649-652.

35. Saitou, N., and M. Nei. 1987. The neighbor-joining method: a new method for reconstructing phylogenetic trees. Mol. Biol. Evol. 4:406-425.

36. Schleifer, K. H. 1985. Analysis of the chemical composition and primary structure of murein. Methods Microbiol. 18:123-156.

37. Schleifer, K. H., and O. Kandler. 1972. Peptidoglycan types of bacterial cell walls and their taxonomic implications. Bacteriol. Rev, 36:407-477.

38. Schleifer, K. H., and P. H. Seidl. 1985. Chemical composition and structure of murein, p. 201-219. In M. Goodfellow and D. E. Minnikin (ed.), Chemical methods in bacterial systematics. Academic Press, London, United King dom.

39. Schumann, P., H. Prauser, F. A. Rainey, E. Stackebrandt, and P. Hirsch. 1997. Friedmanniella antarctica gen. nov., sp. nov., an LL-diaminopimelic acid-containing actinomycete from antarctic sandstone. Int. J. Syst. Bacteriol. 47:278-283

40. Stackebrandt, E., V. J. Fowler, F. Fiedler, and H. Seiler. 1983. Taxonomic studies on Arthrobacter nicotianae and related taxa: description of $A r$ throbacter uratoxydans sp. nov. and Arthrobacter sulfureus sp. nov. and reclassification of Brevibacterium protophormiae as Arthrobacter protophormiae comb. nov. Syst. Appl. Microbiol. 4:470-486.

41. Stackebrandt, E., C. Koch, O. Gvozdiak, and P. Schumann. 1995. Taxonomic dissection of the genus Micrococcus: Kocuria gen. nov., Nesterenkonia gen. nov., Kytococcus gen. nov., Dermacoccus gen. nov., and Micrococcus Cohn 1872 gen. emend. Int. J. Syst. Bacteriol. 45:682-692.

42. Stackebrandt, E., R. M. Kroppenstedt, K.-D. Jahnke, C. Kemmerling, and H. Gürtler. 1994. Transfer of Streptosporangium viridogriseum (Okuda et al. 1966), Streptosporangium viridogriseum subsp. kofuense (Nonomura and Ohara 1969), and Streptosporangium albidum (Furumai et al. 1968) to Kutzneria gen. nov. as Kutzneria viridogrisea comb. nov., Kutzneria kofuensis comb. nov., and Kutzneria albida comb. nov., respectively, and emendation of the genus Streptosporangium. Int. J. Syst. Bacteriol. 44:265-269.

43. Stackebrandt, E., F. A. Rainey, and N. L. Ward- Rainey.1997. Proposal for a new hierarchic classification system of Actinobacteria classis nov. Int. J. Syst. Bacteriol, 47:479-491.

44. Stead, D. E., J. E. Sellwood, J. Wilson, and I. Viney. 1992. Evaluation of commercial microbial identification system based on fatty acid profiles for rapid, accurate identification of plant pathogenic bacteria. J. Appl. Bacteriol. 72:315-321.

45. Uchida, K., and K. Aida. 1984. An improved method for the glycolate test for simple identification of the acyl type of bacterial cell walls. J. Gen. Appl. Microbiol. 30:131-134.

46. Yamada, K., and K. Komagata. 1972. Taxonomic studies on coryneform bacteria. IV. Morphological, cultural, biochemical, and physiological characteristics. J. Gen. Appl. Microbiol. 18:399-416.

47. Yassin, A. F., F. A. Rainey, H. Brzezinka, J. Burghardt, M. Rifai, P. Seifert K. Feldmann, and K. P. Schaal. 1996. Tsukamurella pulmonis sp. nov. Int. J. Syst. Bacteriol. 46:429-436.

48. Yoshimi, Y., A. Hiraishi, and K. Nakamura. 1996. Isolation and characterization of Microsphaera multipartida gen. nov., sp. nov., a polysaccharideaccumulating gram-positive bacterium from activated sludge. Int. J. Syst. Bacteriol. 46:519-525.

49. Zenova, G. M., I. Y. Chernov, T. A. Gracheva, and D. G. Zvyagintsev. 1996. Structure of actinomycete complexes in deserts. Mikrobiologiya 65:616-620.

50. Zhilina, T. N., and G. A. Zavarzin. 1994. Alcaliphilic anaerobic community at pH 10. Curr. Microbiol. 29:109-112.

51. Zhilina, T. N., G. A. Zavarzin, E. N. Detkova, and F. A. Rainey, 1996 Natroniella acetigena gen. nov. sp. nov., an extremely haloalkaliphilic, homoacetic bacterium: a new member of Haloanaerobiales. Curr. Microbiol 32:320-326 